\title{
Prediction of the carbon pool for lacebark pine under future temperature changes
}

\author{
by Chunyi Li ${ }^{1,2}$, Bo Chen ${ }^{3}$, Xiaodong Zhang ${ }^{1,2}$, Xiaoping Wang $^{3}$, Tianshan Zha ${ }^{4}$, Xiaowen Wang ${ }^{1}$
}

\begin{abstract}
The correlation between tree-ring widths of lacebark pine and climate was investigated. Radial growth was positively correlated with monthly mean temperatures in the previous September and significantly negatively correlated with monthly mean and monthly maximum temperatures in March. There was no significant response to levels of precipitation. Treering variation was reconstructed by a transfer function using STD chronology and monthly mean temperatures. Assuming future temperature increases of $1.4^{\circ} \mathrm{C}$ to $4.0{ }^{\circ} \mathrm{C}$ according to IPCC (2006), tree-ring widths would increase by $4.7 \%$ to $12.8 \%$, and lacebark pine carbon pools would increase observably by $10.9 \%$ to $31.1 \%$. Temperature has a positive impact on increasing biomass and hence carbon stored for lacebark pine. The results provide a theoretical reference for forest management and an evaluation of the capacity for forests to sequester carbon under climate change.
\end{abstract}

Key words: lacebark pine, temperature changes, tree-ring growth, biomass, carbon stock

\section{RÉSUMÉ}

Cette étude porte sur la corrélation entre la largeur des anneaux de croissance du pin Napoléon et le climat. La croissance radiale a démontré une corrélation positive avec les températures moyennes du mois de septembre précédent et négative avec les températures moyennes et les températures maximales mensuelles du mois de mars. Le niveau de précipitation ne semblait pas avoir d'effet significatif. La variation dans la largeur des anneaux de croissance a été reproduite au moyen d'une fonction de transfert utilisant une chronologie STD et les températures mensuelles moyennes. Si la température devait augmenter de $1,4{ }^{\circ} \mathrm{C}$ à $4,0^{\circ} \mathrm{C}$ dans le futur, tel que prévu par le GIEC (2006), la largeur des anneaux de croissance pourrait augmenter de $4,7 \%$ à $12,8 \%$ et la rétention de carbone chez le pin Napoléon afficherait une augmentation notable de $10,9 \%$ à $31,1 \%$. La température a un effet positif sur laccroissement de la biomasse et de ce fait sur le carbone séquestré par le pin Napoléon. Les résultats offrent une base théorique pour guider l'aménagement forestier et pour évaluer la capacité des forêts à séquestrer le carbone en réponse aux changements climatiques.

Mots clés : pin Napoléon, changements climatiques, croissance radiale, biomasse, stock de carbone

\section{Introduction}

Forests play an important role in carbon exchange between the atmosphere and the terrestrial biosphere (Dixon et al. 1994, Wolf et al. 2011). A good understanding of the relationship of the changes to forest biomass and carbon pools, growth and climate will help to predict the impact of climate change on forest ecosystems, thus having a vital significance on sustainable forest operations and management, and on the assessment of carbon pool capacities. Tree rings can provide annual proxy climate information, and have been widely used for temperature and precipitation reconstructions over the past several centuries (Cook et al. 2004). China's tree-ring eco-climatology research has focused on sites on the Tibetan Plateau and on other areas of northwestern China (Zhu et al. 2009, Liu et al. 2010, Shi et al. 2013). However, there has been no research on predicting future carbon pools under climate change using the relationship between tree-ring width and climate variability. Lacebark pine (Pinus bungeana Zucc. ex Endl.) is a naturally distributed species in the temperate and subtropical regions of China, ranging from $30^{\circ} 52^{\prime}$ to $38^{\circ} 5^{\prime} \mathrm{N}$ latitude and from $113^{\circ} 15^{\prime}$ to $104^{\circ} 15^{\prime} \mathrm{E}$ longitude (Li et al. 2013). Lacebark pine forests occur naturally in mountainous regions and are widely used as an important plantation species in northern and central China due to their adaptation to dry, cold climates. This study used tree-ring data of the species to analyze radial growth response to climate change. The objectives of the study are: 1 ) to reconstruct the model between tree rings and temperature; and, 2) to predict the carbon pool for lacebark pine under future temperature and precipitation changes.

\footnotetext{
${ }^{1}$ Institute of Wetland Research, Chinese Academy of Forestry, 100091, Beijing, China; ${ }^{\star}$ Corresponding author’s email: chunyili@126.com ${ }^{2}$ Beijing Key Laboratory of Wetland Services and Restoration, 100091, Beijing, China

${ }^{3}$ The College of Forestry, Beijing Forestry University, 100083, Beijing, China

${ }^{4}$ The School of Soil and Water Conservation, Beijing Forestry University, 100083, Beijing, China
} 


\section{Materials and Methods}

\section{Study area}

The study was carried out at sites on Xiaolongshan Mountain approximately $16 \mathrm{~km}$ northeast of Hui county, eastern Gansu Province (Fig. 1). The region has a temperate climate with a 30 -year mean annual temperature of $12.5^{\circ} \mathrm{C}$. Average annual precipitation is $770 \mathrm{~mm}$, of which $438 \mathrm{~mm}$ falls from May to September. The mean annual frost-free period is 209 days and the average growing season is 225 days. These are natural stands with the species composition dominated 93\% 98\% by lacebark pine mixed with Pinus tabulaeformis Carr., Pinus massoniana Lamb., Quercus variabilis Blume and Platycladus orientalis (L.) Franco.

\section{Tree ring and climate data}

Forty-six core samples and 15 disks from 45 trees were collected and after air drying, surfaces were smoothed to ensure an accurate ring count. The image analysis system (WinDENDRO $^{\mathrm{TM}}$ Density 2009, Regent Instruments Canada Inc.) with the precision of $0.001 \mathrm{~mm}$ was used to measure tree-ring width. Quality control of cross-dating used the COFECHA program (Holmes 1983); samples with ambiguities were eliminated. After cross-dating, individual sequences of tree-ring widths were detrended and standardized using the ARSTAN program (Cook and Kairiukstis 1990). All individual index sequences were combined into a single chronology by calculating the bi-weight robust mean. Standard chronology (STD) and residual chronology (RES) were established (Table 1). The mean sensitivities of STD and RES remain between 0.15 and 0.17 , both being at an acceptable level (Kerhoulas and Jeffrey 2011). The STD chronologies are obviously better than those of RES; therefore lacebark pine STD in the study area can better reflect the impact of climatic change on tree-ring growth.

Monthly mean temperatures ( $\mathrm{T}$ mean), monthly mean maximum temperatures ( $\mathrm{T}$ max), monthly mean minimum temperatures ( $\mathrm{T} \mathrm{min}$ ) and monthly precipitation ( $\mathrm{P}$ mean) were obtained for Baoji Weather Station $\left(34^{\circ} 21^{\prime} \mathrm{N}, 107^{\circ} 08^{\prime} \mathrm{E}\right)$ from the China Meteorological Data Sharing Service System (http://cdc.cma.gov.cn). The records cover the years 1958 to 2009.

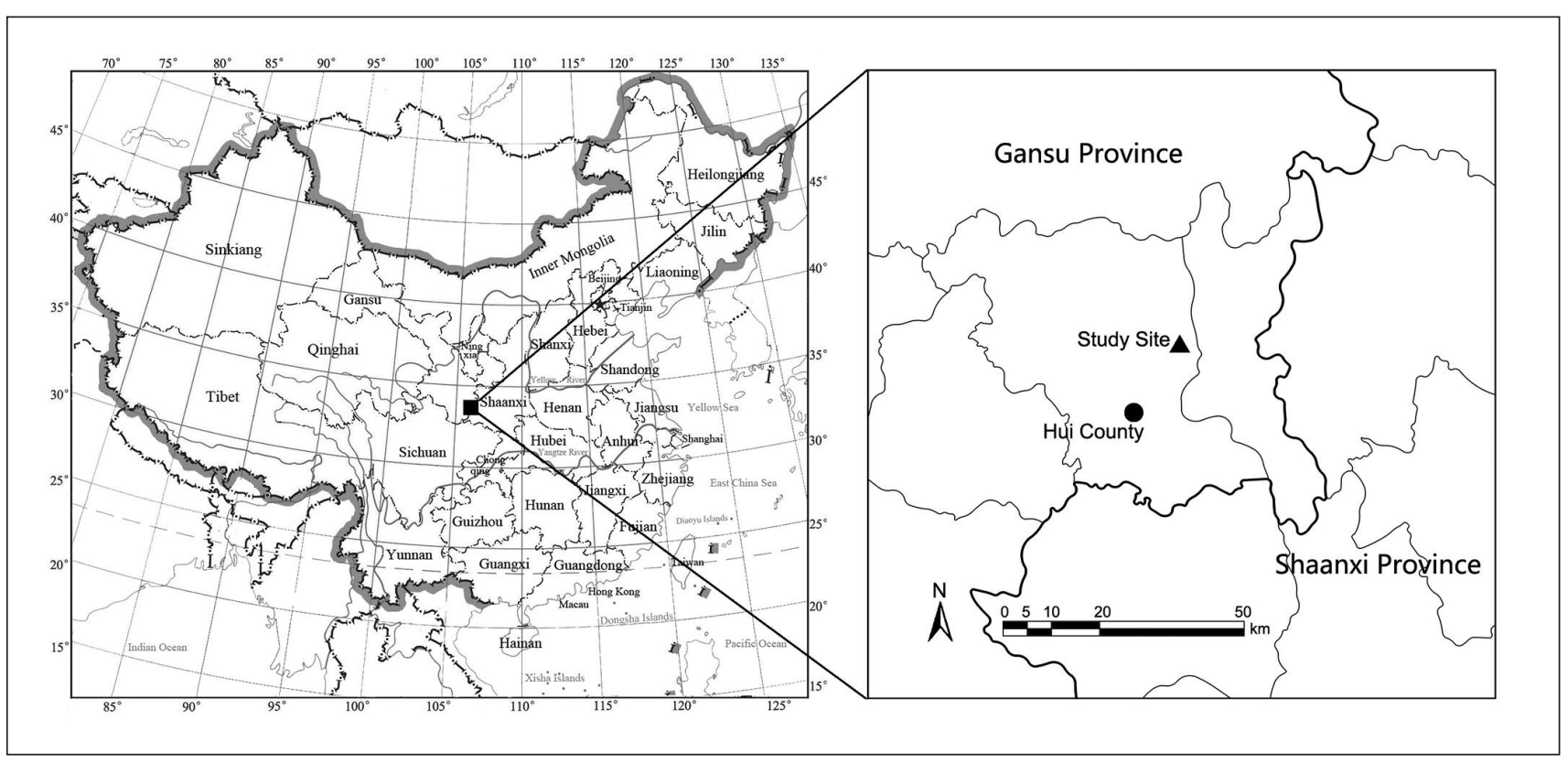

Fig. 1. Location of the study area

Table 1. Chronology characteristics and common analysis of STD and RES chronology of Lacebark pine $(n=55)$.

\begin{tabular}{lcc}
\hline Basic statistics & $\begin{array}{c}\text { Standard } \\
\text { chronology }\end{array}$ & $\begin{array}{c}\text { Residual } \\
\text { chronology }\end{array}$ \\
\hline Mean tree-ring width & 0.942 & 1.001 \\
Mean sensitivity & 0.171 & 0.159 \\
Standard deviation & 0.125 & 0.175 \\
Mean correlation between trees & 0.664 & -0.261 \\
Common interval time span & \multicolumn{2}{c}{$1959-2009$} \\
Mean correlation between trees & 0.347 & 0.293 \\
Signal to noise ratio & 13.692 & 10.890 \\
Expressing population signal & 0.913 & 0.896 \\
Variance in first eigenvector & 37.5 & 33.1 \\
\hline
\end{tabular}

\section{Growth-climate response analysis}

To explore the statistical associations between different monthly-mean climate factors and ring-width indices from 1959 to 2009, the period of tree growth encompassing the previous July to the current October (16 months) for the current tree-ring was selected as the "potential effective climatic window". Individual monthly climate-growth relationships were analyzed using the software DENDROCLIM 2002 (Biondi and Waikul 2004). Based on the results, the optimum monthly assemblies were selected for the growth-climate response analysis. 


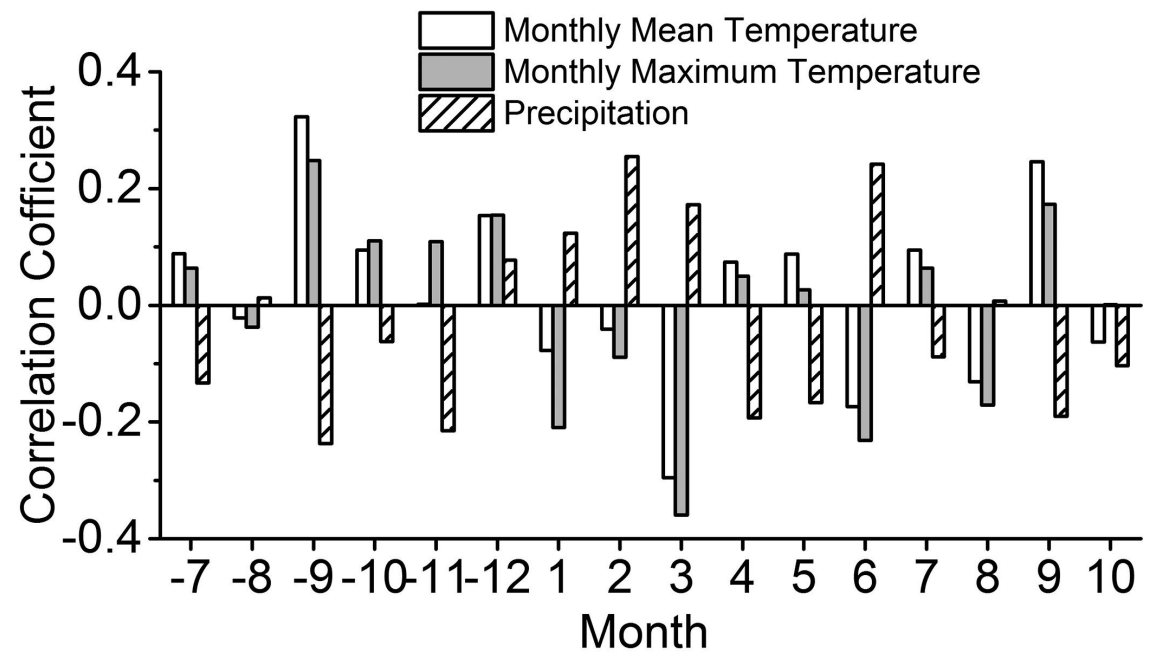

Fig. 2. Correlation between tree-ring width, temperature and precipitation

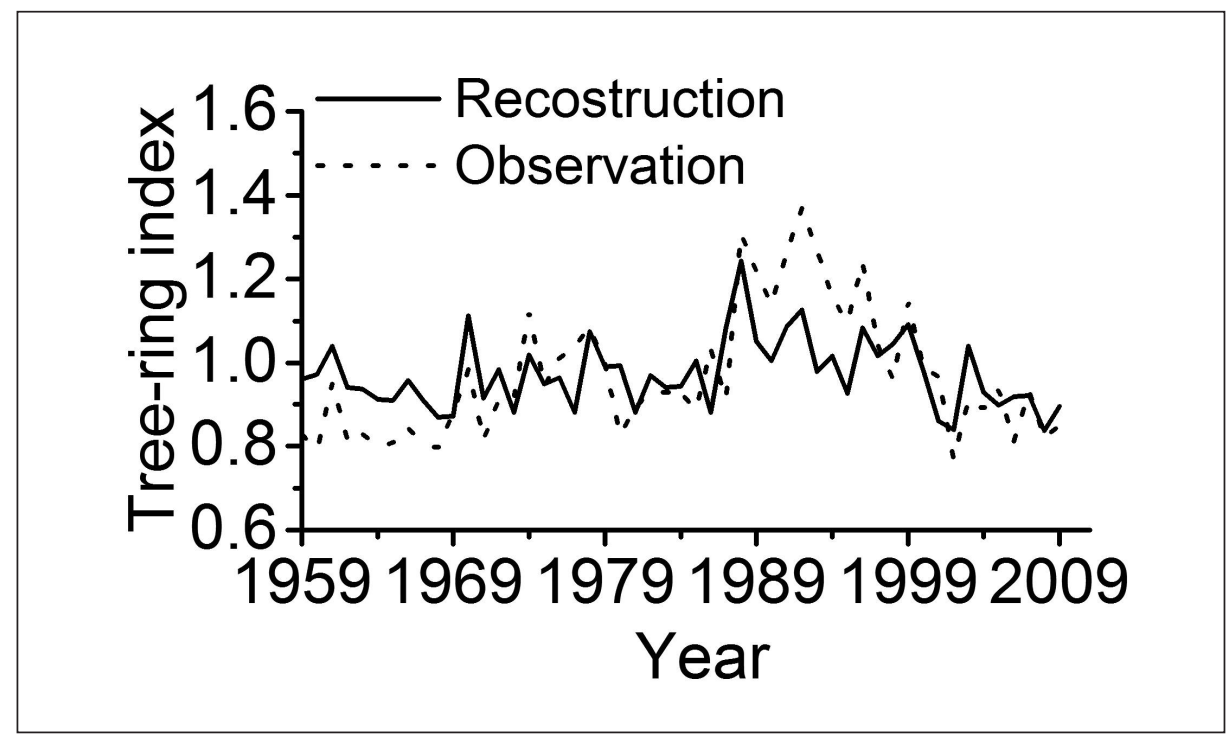

Fig. 3. Comparison of predicted and observed tree-ring width indexes

\section{Results and Discussion \\ Tree-ring climatic response}

Tree-ring width index of lacebark pine was positively correlated with monthly mean temperatures in September, and significantly negatively correlated with mean temperatures and mean maximum temperatures in March (Fig. 2, $p<0.05$ ); however, there was no significant response to precipitation. The development of forests is directly related to climate, and tree species are shifting their ranges in altitude and latitude as a response to changing regional climates (Walther et al. 2002). The growth of different tree species shows certain characteristics in response to climatic factors (Davi et al. 2006). Our results reflect the response pattern of tree-ring growth for lacebark pine to temperature changes and indicate that increasing temperatures in the previous September will lead to wider tree rings, but narrower rings in the current March. This is because monthly mean maximum temperatures in September extend the growing period and significantly increase treering widths. This finding is in agreement with prior findings for Pinus uncinata Ramond ex DC. (Gutiérrez 1991). In spring, high temperatures accelerate evaporation and evapotranspiration, which can result in significant moisture stress for tree growth (Oberhuber et al. 1998). Precipitation in this region is $770 \mathrm{~mm}$ and it is not a limiting factor in the growth of lacebark pine, thus there was no significant response between tree-ring width and precipitation.

Regression model and reconstruction

The transfer function is established by linear regression using STD chronology using monthly mean temperatures in previous Septembers and monthly mean maximum temperatures in current Marchs from 1958 to 2009. The transfer function is as follows:

[1] RWI $_{\mathrm{i}}=0.017-0.034 \times$ $\operatorname{Tmax}_{\mathrm{C} 3 \mathrm{i}}+0.076 \times$ Tmean $_{\mathrm{P} 9 \mathrm{i}}$ $\left(\mathrm{R}^{2}=0.51, \mathrm{~N}=51, p<0.001\right)$

In the equation, $\mathrm{RWI}_{\mathrm{i}}$ stands for the tree-ring width in year $\mathrm{i}$; $\operatorname{Tmax}_{\mathrm{C} 3 \mathrm{i}}$ for the mean maximum temperature of the current March and Tmean $_{\mathrm{P} 9 \mathrm{i}}$ for the mean temperature of the previous September in year $i$.

The correlation coefficient of eq. 1 is 0.5 for the period of 1959 to 2009. Comparison of actual and estimated tree-ring widths during the period (Fig. 3) reveals that change trends are homologous and estimated values agree well with actual values. These findings demonstrate that the reconstruction function is credible. The statistical fidelity of our reconstruction model was evaluated using split-sample calibration-verification and leave-one-out cross-validation methods (Michaelsen 1987; Table 2). The positive values of reduction error (RE) and coefficient of efficiency (CE) demonstrate that the model yields accurate estimates (Fritts 1976, Cook et al. 1999). CE is more rigorous than RE, and values of CE lower than those of RE indicate good regression model ability (Cook et al. 1999). 
Table 2. Regression model statistics for different calibration and verification.

\begin{tabular}{lccc}
\hline & $\begin{array}{c}\text { Calibration } \\
(\mathbf{1 9 5 9 - 1 9 8 4 )}\end{array}$ & $\begin{array}{c}\text { Calibration } \\
(\mathbf{1 9 8 5 - 2 0 0 9 )}\end{array}$ & $\begin{array}{c}\text { Full calibration } \\
(\mathbf{1 9 5 9 - 2 0 0 9 )}\end{array}$ \\
\hline$R$ & 0.726 & 0.691 & 0.714 \\
$R^{2}$ & 0.527 & 0.477 & 0.510 \\
$\mathrm{RE}$ & 0.614 & 0.573 & 0.424 \\
$\mathrm{CE}$ & 0.475 & 0.362 & - \\
\hline
\end{tabular}

$R$-correlation coefficient; $R^{2}$-variance explained by the regression model; RE-reduction of error statistic; CE-coefficient of efficiency.

\section{Prediction of carbon storage by lacebark pine}

IPCC (2006) suggested that global mean temperatures might rise by $1.4{ }^{\circ} \mathrm{C}$ to $4.0^{\circ} \mathrm{C}$ by 2100 . Supposing that in the three circumstances in 2100 in which global mean temperatures may increase by $1.4^{\circ} \mathrm{C}, 2.7^{\circ} \mathrm{C}$ or $4.0^{\circ} \mathrm{C}$, the increase in annual mean temperatures is caused by the rise of monthly temperatures. Based on the mean values and temperature increments $\left(\Delta \mathrm{T}=1.4^{\circ} \mathrm{C}, 2.7^{\circ} \mathrm{C}, 4.0^{\circ} \mathrm{C}\right)$ and Eq. 1 , the predicted RWI and diameters at breast height (DBHs) of lacebark pine will increase by $4.7 \%, 8.9 \%$ and $12.8 \%$ respectively (Fig. 4 ). According to the biomass equation $\mathrm{Y}=0.232 \times \mathrm{DBH}^{2.247}$ for lacebark pine ( $\mathrm{Li}$ et al. 2014) and carbon concentrations with a mean value of 0.5 (Li et al. 2013), biomass and carbon storage at different DBHs $(10.0 \mathrm{~cm}, 20.0 \mathrm{~cm}, 30.0$ $\mathrm{cm}, 40.0 \mathrm{~cm}$ and $50.0 \mathrm{~cm}$ ) may be predicted. As temperatures rise, biomass and carbon storage significantly increase (Table 3 ). If temperatures increase by $1.4^{\circ} \mathrm{C}$, carbon storage may increase by $2.2 \sim 82.2 \mathrm{~kg} \mathrm{C}$; percentage increases are $10.9 \%$. If temperatures rise by $2.7^{\circ} \mathrm{C}$, carbon storage will increase by 4.3 $\sim 159.7 \mathrm{~kg} \mathrm{C}$; percentage increases are $21.1 \%$. And if temperatures rise by $4.0{ }^{\circ} \mathrm{C}$, carbon storage will increase by $6.3 \sim 235.0 \mathrm{~kg}$ C; percentages increases are $31.1 \%$. Biomass and carbon storage increased as temperatures rose; older trees had larger increases than younger ones. This is in agreement with previous reports that total below-ground biomass increased steadily with age for lacebark pine (Li et al. 2013). The percentage increase for carbon storage remains a constant independent of $\mathrm{DBH}$ for temperatures. Generally, there is a positive correlation between the net primary productivity of forests and temperature (Beuker 1994). When forests are well supplied with water, tree species of most temperate and boreal forests respond to increased temperatures by growing faster and increasing production (Morikawa 1993). Average annual precipitation in the Xiaolongshan Mountain region is $770 \mathrm{~mm}$ and precipitation is not a limiting factor for lacebark pine growth.

In summary, this study notes that temperature has a positive impact on tree-ring widths of lacebark pine in this region. Assuming future temperatures increase up to $4.0^{\circ} \mathrm{C}$, tree-ring widths would increase by up to $12.8 \%$; biomass and carbon pools would increase by percentages of up to $31 \%$. The percentage increase for carbon storage remains a constant independent of $\mathrm{DBH}$ for a temperature increment. These findings are important in predicting growth and evaluation of forest biomass and carbon storage of lacebark in future climate change, which are expected to contribute to improved forest management.

\section{Acknowledgements}

This study was supported by grants from the Fundamental Research Funds for Central Public Welfare Research Institutes (CAFYBB2014QA030), the Science and Technology Program of Beijing Municipal Bureau of Landscape and Forestry (2014-2) and the 948 Program of State Forestry Administration (2130206). Thanks to Gansu Forestry Department and Xiaolongshan Mountain Experiment 
Bureau for permission to access the site and harvest trees. We thank Wang Ben and Gao Faming with assistance in field and laboratory work.

\section{References}

Beuker, E. 1994. Long-term effects of temperature on the wood production of Pinus sylvestris L. and Picea abies (L.) Karst. in old provenance experiments. Scand. J. Forest Res. 9: 34-45.

Biondi, F. and K. Waikul. 2004. DENDROCLIM2002: AC++Program for statistical calibration of climate signals in tree-ring chronologies. Comput. Geosci. 30: 303-311.

Cook, E.R. and L.A. Kairiukstis. 1990. Methods of Dendrochronology: Applications in Environmental Sciences. Kluwer Academic Publishers, Dordrecht, Netherlands.

Cook, E.R., C.A. Woodhouse and C.M. Eakin. 2004. Long-term aridity changes in the western United States. Sci. 306:1015-1018.

Cook, E.R., D.M. Meko, D.W. Stahle and M.K. Cleaveland. 1999.

Drought reconstructions for the continental United States. J. Climate 12: $1145-1162$.

Davi, H., E. Dufrêne and C. François. 2006. Sensitivity of water and carbon fluxes to climate changes from 1960 to 2100 in European forest ecosystems. Agri. Forest Meteorol. 141: 35-56.

Dixon, R.K., A.M. Solomon, S. Brown, R.A. Houghton, M.C. Trexier and J. Wisniewski. 1994. Carbon pools and flux of global forest ecosystem. Sci. 263(5144): 185-190.

Fritts, H.C. 1976. Tree ring and climate. London: Academy Press, $567 \mathrm{pp}$.

Gutiérrez, E. 1991. Climate tree-growth relationships for Pinus uncinata Ram. in the Spanish pre-Pyrenees. Acta Oecol. 12(2): 213-225.

Holmes, R.L. 1983. Computer-assisted quality control in tree-ring dating and measurement. Tree-Ring Bull 43: 69-78.

IPCC. 2006. IPCC guidelines for national greenhouse gas inventory. [EB/OL]. [2006-12-15]. http://www.ipcc-nggip.iges.or.jp/public/2006gl/index.html.
Kerhoulas, L.P. and M.K. Jeffrey. 2011. Sensitivity of ring growth and carbon allocation to climatic variation vary within ponderosa pine trees. Tree Physiol. 32: 14-23.

Li, C.Y., T.S. Zha, J.L. Liu and X. Jia. 2013. Pattern of carbon and nitrogen distribution across a chronosequence of secondary lacebark pine in China. Forest Chron. 89(2): 192-198.

Li, H., C.Y. Li, T.S. Zha, J.L. Liu, X. Jia, X.P. Wang, W.J. Chen and G.M. He. 2014. Patterns of biomass allocation in an age-sequence of secondary Pinus bungeana forests in China. Forest Chron. 90(2): 169-176.

Liu, J.J., B. Yang and C. Qin. 2010. Tree-ring based annual precipitation reconstruction since AD 1480 in south central Tibet. Quaternary Int. doi:10.1016/j.quaint.2010.03.020.

Michaelsen, J. 1987. Cross-validation in statistical climate forecast models. J. Clim. Appl. Meteorol. 26: 1589-1600.

Morikawa, Y. 1993. Climate changes and forests. In: The Potential Effects of Climate Change in Japan. Harasawa, S.N., H. Hashimoto, T. Ookita, K. Masuda and T. Morita (eds.). Center for Global Environmental Research, Tsukuba, Japan, pp: 37-44.

Oberhuber, W., M. Stumbock and W. Kofler. 1998. Climate-treegrowth relationships of Scots pine stands (Pinus sylvestris L.) exposed to soil dryness. Trees 13: 19-27.

Shi, Z.J., J.X. Gao, X.H. Yang, Z.Q. Jia, H. Guo and A.Y. Song. 2013. Tree-ring based reconstruction of mean maximum temperatures since AD 1829. Forest Chron. 89(2): 184-191.

Walther, G.R., E. Post, P. Convey, A. Menzel, C. Parmesan, T.J. Beebee, J.M. Fromentin, O. Hoegh-Guldberg and F. Bairlein. 2002. Ecological responses to recent climate change. Nature, 416 (6879): 389-95.

Wolf, A., P. Ciais, V. Bellassen, N. Delbart, C.B. Field and J.A. Berry. 2011. Forest biomass allometry in global land surface models. Global Biogeochem. Cy. 25: 3015-3030.

Zhu, H.F., X.Q. Fang, X.M. Shao and Z.Y. Yin. 2009. Tree-ring based February-April temperature reconstruction for Changbai Mountain in Northeast China and its implication for East Asian winter monsoon. Climate of the Past 5:1-6. 